\title{
Laparoscopic nephrectomy: analysis of 34 patients $^{1}$
}

\author{
André Luís Alonso Domingos ${ }^{2}$, Ricardo Brianezi Tiraboschi ${ }^{2}$, Rodolfo Borges Reis ${ }^{3}$ Antonio Carlos Pereira Martins ${ }^{4}$ \\ Cassio Bottene Schneider ${ }^{3}$, Sylvio Tucci $\mathbf{J r}^{3}$, Haylton Jorge Suaid ${ }^{3}$, Edson Luis Paschoalin ${ }^{5}$
}

\begin{abstract}
Domingos ALA, Tiraboschi RB, Reis RB, Martins ACP, Schneider CB, Tucci Jr S, Paschoalin EL. Laparoscopic nephrectomy: analysis of 34 patients. Acta Cir Bras [serial online] 2003 vol 18 suppl 5. Available in www.scielo.br/acb

ABSTRACT - Objective: To analyze the clinical experience of laparoscopic nephrectomy for benign and malignant diseases at a university hospital. Methods: From February 2000 to March 2003, 34 patients (14 men and 20 women) underwent transperitoneal laparoscopic total nephrectomy at the Hospital das Clinicas - FMRP-USP: 28 (82.3\%) patients had benign diseases and 6 (17.7\%) malignant neoplasias. Benign diseases were represented by: urinary stones $(\mathrm{N}-9,32.1 \%)$, chronic pyelonephritis $(\mathrm{N}-8,28.6 \%)$, vesicoureteral reflux $(\mathrm{N}-4,14.3 \%)$, ureteropelvic obstruction $(\mathrm{N}-3,10.7 \%)$, multicystic kidney $(\mathrm{N}-2,7.1 \%)$ and pyonephrosis $(\mathrm{N}-2$, 7.1\%). Patients age range was 2-79 years (mean - 35,1 years). Results: In 32/34 patients the procedures were accomplished successfully. In $2(5.8 \%)$ cases of pyonephrosis, open conversion was necessary due to perinephric abscess and difficulties in dissection of renal hilum. Two patients had intraoperative complications (1 duodenum serous laceration an 1 vascular lesion of renal hilum), but both were managed laparoscopically. Two $(5.8 \%)$ post operative complications ( 1 delayed bleeding and 1 pancreatic fistula) required open surgical exploration. The mean time of hospital stay was 58h (18 to 240h). Conclusion: Laparoscopic nephrectomy proved to be a method safe and associated with a low rate of morbidity, shorter hospital stay and no casualties.
\end{abstract}

KEY WORDS: Nephrectomy. Laparoscopy.

\section{INTRODUCTION}

Since the report of the first laparoscopic nephrectomy by Clayman in $1990^{1}$, the method deserved widespread investigation and use. The advances in technology of instrumentation as well as the establishment of surgical training programs led to execution of more complex procedures in a shorter surgical time.

Despite the fact of the difficulties to perform nephrectomy in cases of pyonephrosis and severe pyelonephritis the technique is considered safe for the treatment of benign and malignant diseases of the kidney ${ }^{2,3,4,5}$. Laparoscopic nephrectomy allows better esthetic results, lower morbidity, lesser postoperative pain, shorter hospital stay and faster return to normal activities than open surgery ${ }^{6,7}$. A longer learning curve and a higher cost of equipment that represent an apparent disadvantage of laparoscopic surgery is counterbalanced by the aforementioned advantages which compares favorably to open surgery ${ }^{8}$.

The aim of this study is to analyze the results of the first 34 laparoscopic consecutive nephrectomies carried out at our institution.

\section{METHODS}

We revised the records of 34 patients (age range: 2 to 79 years; mean: $35.1+18.7$ years) submitted to transperitoneal laparoscopic total nephrectomy, at the Hospital das Clínicas -
FMRP-USP, from February of 2000 till March of 2003. Fourteen were men and 20 women. The diagnosis was benign disease in $28(82.3 \%)$ and malignant tumor in $6(17.7 \%)$. The benign diseases responsible for kidney functional exclusion were: urinary stone in 9 cases $(32.1 \%)$, chronic pyelonephritis in 8 (28.5\%), vesicoureteral reflux in $4(14.3 \%)$, ureteropelvic junction obstruction in $3(10.7 \%)$, multicystic kidney in $2(7.1 \%)$ and pyonephrosis in $2(7.1 \%)$. All 6 patients with malignant disease had hypernephroma stage $\mathrm{T} 1 \mathrm{~N} 0 \mathrm{M} 0^{9}$ (tumor size $<5 \mathrm{~cm}$ in 5 and $6 \mathrm{~cm}$ in 1 ).

Patients were operated on under general anesthesia and received $1 \mathrm{~g}$ of intravenous cefazoline $1 \mathrm{~h}$ before the beginning of surgery followed by 2 additional doses with intervals of $8 \mathrm{~h}$.

Patients were placed on operating table in supine position tilted $45^{\circ}$ toward the opposite side of the elected for surgery. A Foley catheter was placed in the bladder for $12-24 \mathrm{~h}$. In 32 patients the pneumoperitoneum with $\mathrm{CO} 2$ gas was established with a Veress' needle while in 2 the first port was created through a small open incision (Hasson). During the procedure the pressure of pneumoperitoneum was kept in 12 $\mathrm{mmHg}$ by an automatic $\mathrm{CO} 2$ gas insufflator $\left(\right.$ Astus $\left.^{\mathrm{TM}}\right)$. A four-port technique was preferred in the following locations: mid-clavicular line (level of umbilicus $-10 \mathrm{~mm}$ ), anterior axillary's line ( 2 ports of $10 \mathrm{~mm}$ each) and posterior axillary's line (1 port $-10 \mathrm{~mm})$.

\section{RESULTS}

Surgeries lasted for 180 to 400 minutes (mean 240 minutes - Table 1). Curiously no difference in operating time was observed between procedures for benign or malignant diseases. Hospital stay varied from 18 to $240 \mathrm{~h}$ with a mean of 58h. Two patients had a prolonged hospitalization due to complications of concomitant diseases (atrial fibrillation and Diabetes Mellitus, respectively $144 \mathrm{~h}$ and $240 \mathrm{~h}$ ).

We had two intraoperative complications: 1 injury of duodenal serous (right nephrectomy) and 1 lesion of vascular renal hilum (left nephrectomy). Both were managed properly without necessity of conversion to open surgery (Table 2).

TABLE 1: Hospital stay and operating time.

\begin{tabular}{l|c|c}
\hline & Time range & Mean \\
\hline Operating time $(\min )$ & $180-400$ & 240 \\
\hline Hospital stay $(\mathrm{h})$ & $18-240$ & 58 \\
\hline
\end{tabular}

1. This research was carried out at the Hospital das Clinicas - FMRP-USP

2. Medical Residents / Hospital das Clinicas - FMRP-USP

3. Assistant Professor of Urology / Hospital das Clinicas - FMRP-USP

4. Professor of Urology / Hospital das Clinicas - FMRP-USP

5. Post graduation alumni / FMRP-USP 
TABLE 2: Surgical complications of 34 laparoscopic nephrectomy.

\begin{tabular}{c|c|c|c}
\hline Moment & Complication & $\mathbf{N}$ & $(\boldsymbol{\%})$ \\
\hline \multirow{2}{*}{ Intraoperative } & Bowel injury & 1 & 2,9 \\
\cline { 2 - 4 } & Vascular injury & 1 & 2,9 \\
\hline \multirow{2}{*}{ Postoperative } & Pancreatic fistula & 1 & 2,9 \\
\cline { 2 - 4 } & Hemorrhage & 1 & 2,9 \\
\hline
\end{tabular}

Two $(5.8 \%)$ of 34 patients required conversion to open access in consequence of the presence of perinephric abscesses which did not allow a safe dissection of renal artery and vein.

Postoperative complications occurred in 2 cases: 1 pancreatic fistula and 1 delayed bleeding. These 2 patients required open surgical intervention and recovered completely.

Only the patient that showed delayed postoperative hemorrhage required blood transfusion.

\section{DISCUSSION}

The length time of laparoscopic nephrectomy depends on the surgeon specific skill dictated by the learning curve ${ }^{2}$. Our data showed a mean operating time of 240 minutes which is similar to that seen in some reports ${ }^{2,3}$ but longer than others that refer lower means as 90 minutes $^{6}$. It is worth while to mention that most procedures of our series were performed by medical residents. Injury of abdominal viscera and bleeding are the most common complications of laparoscopic nephrectomy ${ }^{2}$. The rate of $5.8 \%$ of such intercurrences observed in our data is comparable to those published elsewhere ${ }^{2,4,10}$.

Conversion to open surgery was necessary in $5.8 \%$ of our patients which is in the upper limit of the rate range reported previously $y^{2,3,10}$. New surgical interventions in the postoperative period to manage complications in $5.8 \%$ of cases is similar to data reported previously ${ }^{2,10}$.

The mean hospital stay of $58 \mathrm{~h}$ reflects the low morbidity of the method and is in accordance with the literature $e^{2,3,6,7}$.

\section{CONCLUSION}

Laparoscopic nephrectomy proved to be a method safe and associated with a low rate of morbidity, shorter hospital stay and no casualties.

\section{REFERENCES}

1. Clayman RV, Kavoussi LR, Soper NJ. Laparoscopic nephrectomy: initial case report. J Urol 1991; 146:278-82.

2. Rassweiler J, Fornara P, Weber M, Janestek G, Fahlenkamp D, Henkel T, Beer M, Stackl W, Boeckmann W, Recker T, Lampel A, Fischer C, Humke U, Muller K. Laparoscopic nephrectomy: the experience of the laparoscop working group of the German Urologic Association. J Urol 1998; 160:18-21.

3. Kerbl K, Clayman RV, Mc Dougall EM, Kavoussi LR. Laparoscopic nephrectomy: the Washington University experience. Br J Urol 1994; 73:231-6.

4. Cadeddu JA, Ono Y, Clayman RV, Kavoussi LR Barret PH, Janestek G, Fentie DD, McDougall EM, Moore RG, Kinukawa T, Elbahnasy AM, Nelson JB, Kavoussi LR. Laparoscopic nephrectomy for renal cell cancer: evaluation of efficacy and safety: a multicenter experience. Urology 1998; 52: 773-7.

5. El Fettouh HA, Rassweiller JJ, Schulze M, Salomon L, Allan J, Ramakumar S, Jarret T, Abbou CC, Toley DA, Kavoussi LR, Gill IS Laparoscopic radical nephroureterectomy: results of an international multicenter study. Eur Urol 2002; 42: 447-52.

6. Fornara P, Doehn C, Friederich HJ, Jocham D. Nonrandomized comparison of open versus laparoscopic nephrectomy in 249 patients with benign renal disease. Eur Urol 2001; 40: 24-31.

7. Parra RO, Perez MG, Boullier JA, Cummings JM. Comparison between standart flank versus laparoscopic nephrectomy for benign renal disease. J Urol 1995; 153:1171-3.

8. Lotan Y, Gettman MT, Roehrborn CG, Pearle MS, Cadeddu JA. Laparoscopic nephrectomy is cost effective compared with open nephrectomy in a large county hospital. JSLS 2003; 7: 111-5.

9. Javidan J, Stricker HJ, Tamboli P, Amin MB, Peabody JO, Deshpande A, Menon M. Prognostic significance of the 1997 TNM classification of renal cell carcinoma. J Urol 1999; 162: 1277-81.

10. Gill IS, Kavoussi LR, Clayman RV, Ehrlich R, Evans R, Fuchs G, Gersham A, Hulbert JC; McDougall EM, Rosenthal T. Complications of laparoscopic nephrectomy in 185 patients: a multi-institucional review. J Urol 1995; 154:479-83.

Domingos ALA, Tiraboschi RB, Reis RB, Martins ACP, Schneider CB, Tucci Jr S, Paschoalin EL. Nefrectomia laparoscópica: análise de 34 pacientes. Acta Cir Bras [serial on line] 2003 vol 18 suppl 5. Disponível em www.scielo.br/acb

RESUMO - Objetivo: Relatar a experiência da instituição na realização de nefrectomia laparoscópica para doenças benignas e malignas dos rins. Métodos: Desde fevereiro de 2000 a março de 2003, 34 pacientes (14 homens e 20 mulheres) foram submetidos à nefrectomia transperitoneal laparoscópica no Hospital das Clínicas da Faculdade de Medicina de Ribeirão Preto da Universidade de São Paulo: 28 pacientes $(82,3 \%)$ por doença benigna, e $06(17,6 \%)$ por doença maligna. Os pacientes operados por doença benigna apresentaram exclusão renal pelas seguintes etiologias: litíase $(\mathrm{N}=9,32,1 \%)$, pielonefrite crônica $(\mathrm{N}=8,28,6 \%)$, refluxo vesicoureteral $(\mathrm{N}=4,14,3 \%)$, estenose de JUP $(\mathrm{N}=3,10,7 \%)$, rim multicístico $(\mathrm{N}=2,7,1 \%)$ e pionefrose $(\mathrm{N}=2,7,1 \%)$. A idade variou entre 2 e 79 anos (média de 35,16 anos). Resultados: dos 34 procedimentos, 31 (91,1\%) foram completados com sucesso pelo método laparoscópico, sendo necessárias apenas 02 (5,8\%) conversões para nefrectomia aberta (pionefrose) e $02(5,8 \%)$ reintervenções cirúrgicas. O tempo operatório médio foi de 240 minutos (180 à 400 minutos). Dois pacientes $(5,8 \%)$ apresentaram complicações intraoperatórias, sendo 01 lesão de serosa duodenal e 01 lesão de pedículo renal, ambas controladas por laparoscopia. Reintervenção cirúrgica foi necessária em 2 pacientes $(5,8 \%)$. O tempo médio de internação hospitalar foi de $58 \mathrm{~h}$ (variando de 18 a $240 \mathrm{~h}$ ). Conclusão: a nefrectomia laparoscópica apresentou baixo índice de complicações, curto período de internação e ausência de mortalidade, mesmo quando realizada no início da curva de aprendizado.

DESCRITORES - Nefrectomia. Laparoscopia.

\section{Correspondência:}

Antonio Carlos Pereira Martins

Departamento de Cirurgia - HCFMRP-USP

Av. Bandeirantes, 3.900, $9^{\circ}$ Andar

Ribeirão Preto, SP, CEP: 14048-900 